This item was submitted to Loughborough's Research Repository by the author.

Items in Figshare are protected by copyright, with all rights reserved, unless otherwise indicated.

\title{
Standardization and pre-assembly- distinguishing myth from reality using case study research
}

PLEASE CITE THE PUBLISHED VERSION

http://www.tandfonline.com/doi/abs/10.1080/01446190010020435

PUBLISHER

(C) Taylor and Francis

VERSION

AM (Accepted Manuscript)

LICENCE

CC BY-NC-ND 4.0

REPOSITORY RECORD

Gibb, Alistair G.F.. 2019. "Standardization and Pre-assembly- Distinguishing Myth from Reality Using Case Study Research". figshare. https://hdl.handle.net/2134/9019. 
This item was submitted to Loughborough's Institutional Repository (https://dspace.lboro.ac.uk/) by the author and is made available under the following Creative Commons Licence conditions.

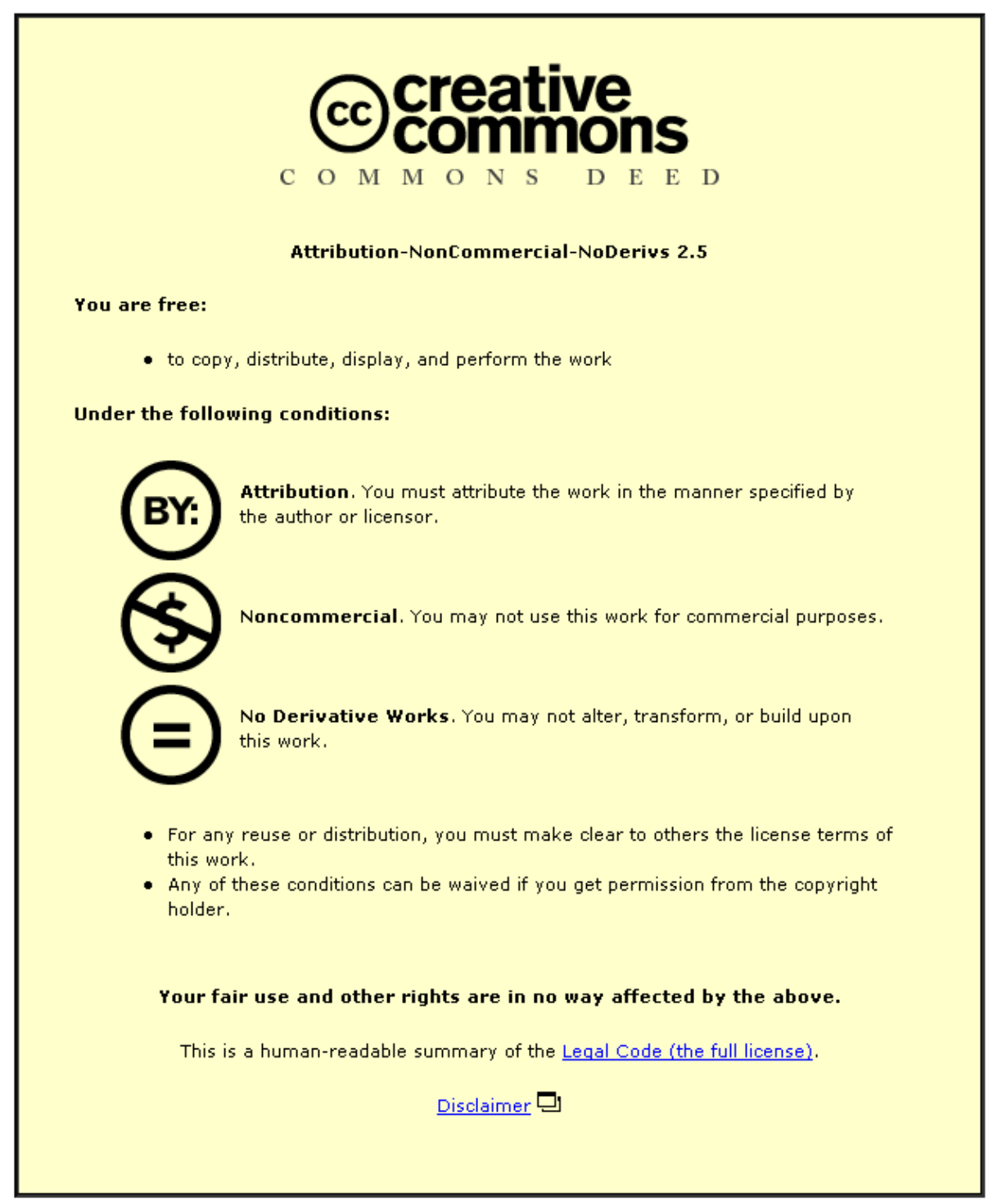

For the full text of this licence, please go to: http://creativecommons.org/licenses/by-nc-nd/2.5/ 


\title{
Standardisation and Pre-assembly - distinguishing myth from reality using case study research
}

\author{
Alistair G F Gibb \\ Loughborough University \\ Invited paper for special edition of Construction Management \& Economics \\ Gibb, A (2001) Standardization and pre-assembly - distinguishing myth from reality using case \\ study research. Construction Management \& Economics 19(3):307-315
}

\begin{abstract}
Standardisation and pre-assembly (S\&P) are not new, but their application and their drivers, pragmatism and perception, need to be considered in the light of current technology and management practice. There are lessons to be learnt from an historical review, but there are also numerous myths that must be dispelled: houses are not cars; maximum standardisation is not always the answer; and, S\&P does not have to cost more.
\end{abstract}

Steven Groák worked with the author on the research project 'Adding value to construction projects through standardisation and pre-assembly' funded by CIRIA (Construction Industry Research \& Information Association). The CIRIA project, which forms the basis of this paper aimed to produce a review of the subject and guidance for clients and project teams through a comprehensive literature review, expert workshops and case study research. The paper defines S\&P, discusses past, present and future applications (providing case study evidence) and presents the key benefits and implications of optimised use of standardisation and pre-assembly.

\section{Introduction}

Over the years and under various guises, standardisation and pre-assembly (S\&P) has been used on construction projects with a view to improve value for money. The approach is not new and, in most senses, not innovative. In fact it seems amazing that S\&P is so poorly understood by many involved in the construction process, especially those involved in procuring construction projects in the UK as demonstrated by the author in a major interview survey of construction clients (CIRIA 2000). This has lead to the inclusion of S\&P in a number of strategies in attempts to cure the ills of the construction industry.

Various exponents from previous eras have presented S\&P both as an expediency and as a design philosophy (e.g. White, 1965; Russell, 1981; Gropius \& Wachsmann in Herbert 1984). Whilst the basic principles have not changed, what is needed is an up-to-date interpretation of how to optimise their use and this debate is brought up to date in this paper. As long as key players claim that they do not use S\&P (even though it is endemic in all construction projects) and as a result fail to manage its application effectively, the potential benefits will not be realised. There has also been a recent increase in interest in S\&P both in the UK and elsewhere with a number of projects and publications (e.g. CIRIA 2000; CIRIA 1999, Sarja 1998; BSRIA 1998; Gibb 1999). Sarja in particular provides a useful international review of the state of the art in open industrialisation. 
In his book 'The Idea of Building', the late Steven Groák commented that he was 'perplexed - but enticed and vastly entertained - by the changing problem of how we mesh, perceive, describe, adjust, redefine or operate for practical purposes the jangling mixtures of building design, building technologies, building science, building production and building use.' He believed that 'their relationship would continue to change, but in ways which would give greater priority to the making of built forms and to the services they offer' (Groák 1992 p.5). Groák was dedicated to observing and reviewing this change critically, as well as contributing to its formation. It was in this context that the author worked with him on a number of S\&P research projects.

The CIRIA (Construction Industry Research and Information Association) research project entitled: 'Adding value to construction projects through S\&P', focussed on value to be gained from the application of S\&P. The research method included workshops, expert interviews and case studies over an 18 month period. The workshops, as the main data gathering activity, covered S\&P principles and strategy, volumetric and nonvolumetric pre-assembly, modular building, component and procedure standardisation. The case studies are summarised later in this paper (Tables $1 \& 2$ ). The work involved more than sixty experts representing the views of clients, contractors, designers and suppliers, and has resulted in two key publications (CIRIA 1997 \& 1999).

These reports introduce S\&P, their implementation on construction projects and their contribution to achieving value for money. The case for S\&P, namely predictability and efficiency is argued and implications for projects and the whole industry are presented. Lessons from non-construction sectors and other countries are brought to bear on construction. The report presents a simple, standardised procedure for optimising S\&P. The report concludes that deliberate, systematic use of S\&P, started early in the process, will add value to projects by increasing predictability and efficiency. This work is now being developed in a further CIRIA project to develop a client's guide for S\&P optimisation (CIRIA 2000).

The CIRIA project forms the framework for this paper along with review information from Groák's 'The Idea of Building'. The paper defines S\&P and its drivers, pragmatism and perception, as they are understood at the turn of the millennium. Through a brief historical and contemporary review several myths and legends are exposed and the realities of modern applications of S\&P are presented.

\section{S\&P - Past, present and future}

\subsection{Developing a better understanding of S\&P}

Standardisation is the extensive use of components, methods or processes in which there is regularity, repetition and a background of successful practice and predictability. Some items are standard by their nature (generic standardisation), or their country of origin (national standardisation). Both clients and suppliers may have standard processes or products. As a minimum, project teams should do what ever they can to standardise across the project. Benefits that can be obtained from such standardisation during the manufacturing phase can be seen from Figure 1. 


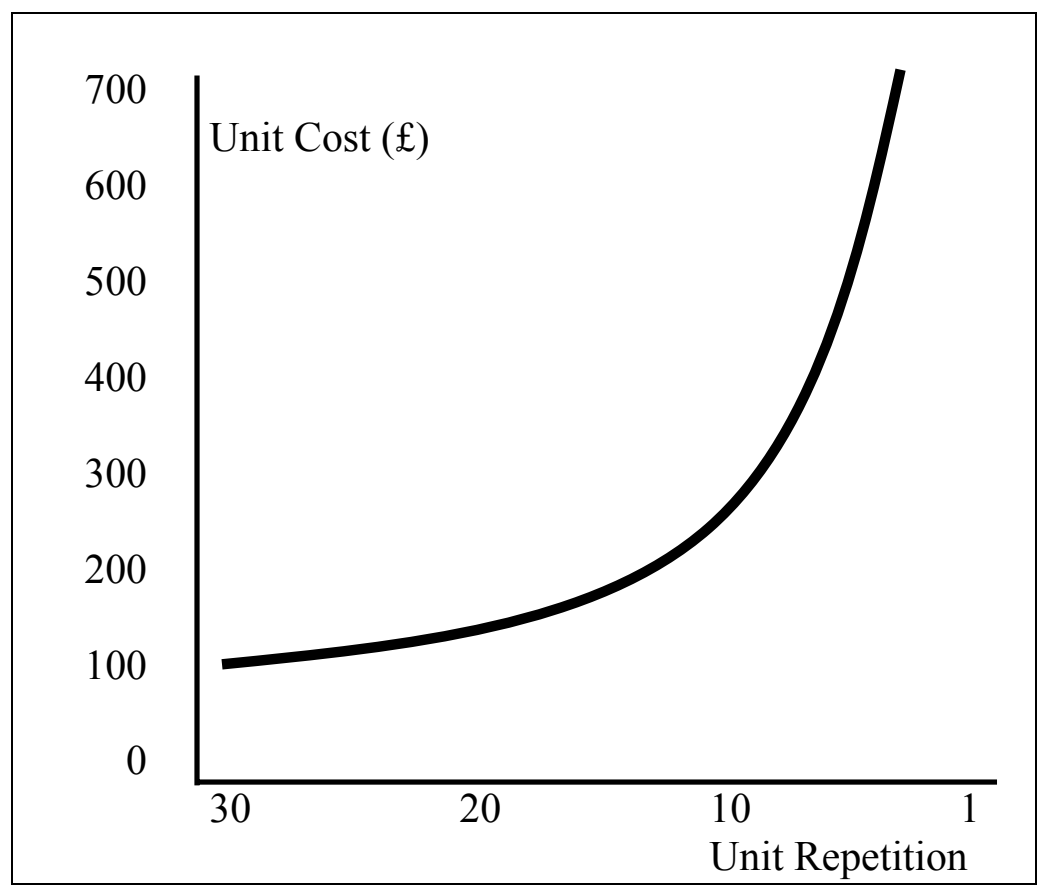

Figure 1 Relationship between unit cost and unit repetition (standardisation) for precast concrete cladding Courtesy of Trent Concrete

(adapted from Gibb 1999)

Historically, those taking standardisation seriously (e.g. Gropius in Russell 1959 p.48) have always struggled to resolve the conflict between uniformity and variation, between maximum standardisation and flexibility. This conflict has still not been resolved - it remains as a tension that sometimes leads to design impotence, but should be used to ensure optimal implementation (see section 2.3.2). Standardisation works by ensuring accurate fit and interchangeability of components - thus the most important area for standardisation is actually the interfaces between the components rather than the components themselves.

Many different terms are used to describe the process of pre-assembly. They are often used inappropriately and with little understanding, both historically (White, 1965 p.3) and today (CIRIA 2000). The following definitions have been developed by the author since the CIRIA project and seek to bring some cogency to the use of terms:

- Component Manufacture and sub-assembly

Many components used in construction are actually sub-assemblies (e.g. door furniture or light fittings). This category includes all small-scale sub-assemblies that would never be considered for on-site assembly in any developed country. Their use is outside the scope of this paper.

- Non-volumetric pre-assembly

These items are assembled in a factory, or at least prior to being placed in their final position. They may include several sub-assemblies and constitute a significant part of the building or structure. Examples include wall panels, structural sections and pipework assemblies.

- Volumetric pre-assembly

These items are also assembled in a factory. They differ from non-volumetric in that they enclose usable space and are usually installed on site within an 
independent structural frame. Examples include toilet pods, plant room units, preassembled building services risers and modular lift shafts.

\section{- Modular building}

These items are similar to volumetric units, but in this case the units themselves form the building, as well as enclosing useable space. They may be clad externally on-site with 'cosmetic' brickwork as a secondary operation. Examples include outof-town retail outlets (McDonald's Drive-Thru), office blocks and motels (Forte, Friendly etc.) as well as concrete multi-storey modular units used for residential blocks in Korea (now also used for UK prison buildings).

These definitions were developed independently by the author following close evaluation of contemporary applications. However, it is significant that they agree very closely with historical definitions, despite the changes in technology. White (1965 p.3) describes four degrees of prefabrication as 'pre-cutting; panel fabrication; volume enclosing sections; and, manufacture of complete dwelling units as the ultimate'.

\subsection{History and Philosophy of S\&P}

'Some components have been standardised over centuries - such as bricks and tiles and there exists an enticing set of myths to justify each standard. The use of modular frameworks has existed for centuries (e.g. in Europe since the early Renaissance). However, the real drive to combine standardisation with systematic building grew with the development of the off-site fabrication shops and the factory-based building component industry' (Groák 1992 p.134). Having reviewed the historical S\&P debate, this paper contends that there are two fundamental drivers for S\&P, namely: pragmatism - industry response to an urgent need combined with a lack of resource; and, perception - client and public reaction to a prevailing design philosophy.

Industry's pragmatic response to an urgent need encapsulates the wax and wane of S\&P since the start of the industrial revolution. The export of prefabricated houses supported the colonial expansion of European nations, where there was an urgent need for shelter and a distinct lack of locally available materials and labour (at least to suit the tastes of the Europeans). In the mid- $19^{\text {th }}$ century Brunel developed standardised, prefabricated hospitals for the war in the Crimea. The army had the urgent need with no local solution available. UK fabricators responded to the need for housing combined with the acute shortage of skilled labour following the two world wars (after 1918 and 1945). Herbert (1978 p.2), commenting on historical applications of S\&P, recognised this motive for S\&P where 'local demand, generated by unusual circumstances, exceeded the local capacity to supply the buildings so urgently needed.'

In some parts of the world (e.g. Singapore) there has been a recent urgent need for housing that has been addressed by S\&P. However, in Europe the residential need is not for significant numbers of low-cost units and, as such, the urgent need no longer exists. In Europe the needs have changed, with society now dominated by leisure and travel. Interestingly, it is in these areas of need that contemporary S\&P is seeing its main opportunity (e.g. McDonald's Drive-Thru, Whitbread public houses, Forte hotels, BAA airport developments, and fuel outlets for Shell \& Esso) compared with houses and schools during the last period of UK S\&P growth in the 1950s and '60s. Opportunities for S\&P in the UK residential sector still appear limited, despite positive experience from other countries such as the Netherlands and Japan (Gibb 1999). 
Alongside this pragmatic response lies the issue of design philosophy, or more particularly clients and the public's perception of it and reaction to it. Historical proponents of S\&P such as Wachsmann, Gropius and Le Corbusier approached the issues from the angle of idealistic design purity - 'better architecture for a better world' (Herbert (1965) on Gropius). This paper argues that the prevailing public mood at that time, notwithstanding a few traditionalists, was to support these ideals as part of the 'brave new world', where everything new was to be espoused and everything traditional denigrated.

However, client and public perception of design has changed. Emphasis now falls on achieving value for money, zero defects, minimal waste and achieving minimum environmental impact. Innovation plays a leading role in both the recent UK Government-sponsored reports on the way forward in achieving the targets set for construction (Latham 1994 and Egan 1998). S\&P is seen as one of the ways that these targets can be met. This paper also contends that today's public is reluctant to accept the modernist philosophy. Instead they demand maximum choice and appear to be comfortable with pre-assembled buildings looking as though they are produced conventionally (CIRIA 1999). This has lead to the demand for mass customisation rather than mass production. This is where the benefits of mass production can creatively be combined with systems that offer greater choice for the individual customer, provide improved control of the total construction process, and flexibility of assembly options. This demand can be met through developments in manufacturing, such as digitally controlled machines, automation and electronic data interchange.

The CIB international Working Commission 24 'Open Industrialisation in Building' supports this view stating that 'the technical, architectural goals and realisation of industrialised building changed most during the 1980s and 1990s. The current technology is flexible for individual architectural designs allowing easy alterations during use, future changes and modernisation. For this aim, systematic modular design and products are applied, including dimensional modularity, tolerance system, compatible joints and use of modular products.' (Sarja 1998 p.15).

Groák (1992 p.124) explains that the 'extensive system of factory-produced materials and components has changed the building process out of all recognition. Designers can assume the availability of off-the shelf components; they can also assume the availability of special variations from those factories, based upon the stock designs and expert manufacturing advice.' He found that the 'result has been a tendency to greater use of prefabricated components, standardisation of construction and the development of work packages - distinct elements of the building designed to suit a given subcontractor/manufacturer' (Groák 1992 p.124).

It is important that we learn from history. The CIRIA project used several historical case studies to describe how the application of S\&P has developed over the years. These are described in Table 1 along with the key lessons. 


\begin{tabular}{|c|c|c|}
\hline Project & Main S\&P application & Key lessons \\
\hline $\begin{array}{l}\text { Crystal } \\
\text { Palace, } \\
\text { London } \\
1851\end{array}$ & $\begin{array}{l}3 \text { storey exhibition hall } \\
\text { Factory-made iron, timber \& glass } \\
\text { components } \\
\text { Re-located from original site }\end{array}$ & $\begin{array}{l}\text { First project to closely link site and factory processes } \\
\text { Maximum standardisation } \\
\text { Drastic time and cost savings } \\
\text { On-site painting then took considerable time } \\
\text { Pre-assembly allowed re-location and re-erection } \\
\text { Project team make up very different to today - more } \\
\text { emphasis on individuals }\end{array}$ \\
\hline $\begin{array}{l}\text { British } \\
\text { Hospital, } \\
\text { Renkioi } \\
1855\end{array}$ & $\begin{array}{l}\text { Crimean war hospital } \\
\text { Prefabricated timber units, } \\
\text { shipped from UK to Turkey } \\
\text { Modular layout and some details } \\
\text { were standardised }\end{array}$ & $\begin{array}{l}\text { Cheapest and lightest building constructed up to then } \\
\text { Overall project duration reduced to } 6 \text { months } \\
\text { Small, skilled erection team ensured quality but took } \\
\text { time } \\
\text { Allowed controlled construction in an unknown location } \\
\text { Approach developed for several further applications } \\
\text { Process driven by committed individual (Brunel) }\end{array}$ \\
\hline $\begin{array}{l}\text { Royal } \\
\text { Albert } \\
\text { Bridge, } \\
\text { Saltash } \\
1859\end{array}$ & $\begin{array}{l}\text { One of the earliest extant examples } \\
\text { of pre-assembly } \\
\text { Wrought iron trusses assembled on } \\
\text { the banks then floated into position }\end{array}$ & $\begin{array}{l}\text { Most economical engineering work in existence (Client) } \\
\text { Pre-assembly was considered right at the start } \\
\text { Careful and detailed planning is essential } \\
\text { Pioneer project for many future bridges }\end{array}$ \\
\hline $\begin{array}{l}\text { Charles } \\
\text { Eames } \\
\text { House, } \\
\text { USA } \\
1949\end{array}$ & $\begin{array}{l}\text { House built entirely of mail-order } \\
\text { components } \\
\text { Unashamedly part of the modernist } \\
\text { ideology }\end{array}$ & $\begin{array}{l}\text { Use of standardised components allowed a cheap, swiftly } \\
\text { erected building and a successful permanent house } \\
\text { Principles not embraced by industry } \\
\text { Public did not like the materials }\end{array}$ \\
\hline $\begin{array}{l}\text { CLASP, } \\
\mathrm{UK} \\
1957 \text { to } \\
\text { date }\end{array}$ & $\begin{array}{l}\text { Standardised system for } \\
\text { educational buildings } \\
\text { Lightweight, pin-jointed steel } \\
\text { frame, lattice trusses, precast slabs }\end{array}$ & $\begin{array}{l}\text { Main success due to the scale of implementation } \\
\text { Originally a solution for subsidence but used widely } \\
\text { Overall time scale reduced by } 18 \% \\
\text { Main cost savings from less labour, pre-contract input, } \\
\text { contract periods, cost over-runs and delays } \\
\text { Still in use after } 40 \text { years and many modifications }\end{array}$ \\
\hline
\end{tabular}

Table $1 \quad$ Historical case studies from CIRIA S\&P Research

\subsection{Myths and legends of S\&P}

\subsubsection{Houses are like cars}

For the last few years there has been a clamour to draw parallels between automotive manufacturing and the production of buildings. But this comparison is not new, for example, Gropius argued that 'industrial production of complete buildings could be analogous with the mass production of the motor car' (Herbert 1959 p.17). However, whilst there are clearly building lessons to be learnt from much of the manufacturing sector many of the trite comparisons are hard to substantiate. For example, Groák (1992 p.123) states that 'buildings are fixed to the ground, which means that we have to have a mobile industry, an industry which creates a temporary factory to which materials, machines and people are transported. It means that for each project a unique pattern of linkages with materials suppliers and component manufacturers has to be established for all the flows. The common workplace for the assembly of the building leads to a series of confusions characteristic of this process'. With a typically provocative remark Groák adds that 'this interest in the car analogy probably appealed to those who prefer walking 
around a warm, dry factory to struggling across a building site on a cold damp evening'. He then adds that, 'despite the fact that cars can be sold for around ten times as much as houses, on a cost per square metre of usable floor space, there has been a constant assumption that they can be equated and therefore that we should transfer work from the house-building site into factories.' Gann (1996) makes a similar point stressing that there are 'limits to which manufacturing techniques derived from the car industry can be applied to manage the assembly of wide varieties of component parts needed to produce complex customised products (such as buildings). Manufacturers must trade-off the need to achieve economies of scale in the production of standardised factory parts with economies of scope in various stages of assembly in order to provide flexibility to satisfy consumer choices.'

Notwithstanding, there are real lessons that can be drawn from the manufacturing sector, and in particular from the car analogy, including:

- Mass customisation must replace mass production as the modus operandi because technology can now deliver the choice that clients demand

- The customer's needs and desires must be identified and addressed - this will include the need for customisation and the offer of choice

- Most customers will accept that hand-crafted one-off products, if desirable, are likely to cost more and take longer

- Most customers are interested in the end product (the building, or car) but rarely concerned about the processes involved

- The performance of the product (for as long as the customer has it) is as important as its looks

- Customers are interested in value for money, although few can really elucidate exactly what that means

- The supply chain must be acknowledged and managed

- The whole process must be focussed on producing an excellent end-product

- Appropriate pre-assembly and out sourcing of components and sub-assemblies is useful, providing the process is subservient to the delivery of the end product (the tail must not wag the dog)

- Interchangeability and surety of fit will demand close attention to interface or connection design, manufacture and assembly.

\subsubsection{Maximum $S \& P$ is always for the best}

Groák (1992 p. 34) argued that 'there is a school of thought which promotes concepts of buildability, or constructability in the US, based on the attempt to bring a greater awareness of production priorities into the design process. Despite this admirable intention, it is flawed by the implicit assumption that, for one design, there is only one optimum production method. This does not properly recognise the extraordinary variety of production units - and their flexible combinations - in the building industry'. Maximum S\&P is not the only solution to every situation. Consider, for example, the alternative approaches of apparently similar clients BP and Esso in their upgrades of forecourt facilities. One client has gone the route of fully volumetric modular with the other preferring to use flat-pack site assembly. There is clearly a balance between maximum off-site fabrication and the additional costs of transportation (especially where some of the units are largely empty) (Gibb 1999). 
Furthermore, Gray (in Sarja 1998 p145) comments that a 'wholesale switch to standardised components is unlikely to occur unless there are some major changes in design policy and these will only occur if there is a major constraint on cost or construction resource in a period of boom.' He also considers that 'stability of demand which would suit maximum standardisation is only possible by limiting choice, which the UK has so much of and is unlikely to give up; or increasing demand, which is closely allied to the overall economy and is, therefore probably not a viable strategy.'

Herbert (1959 p.21) argues that, contrary to common perception, the modernist architects of the first half of the $20^{\text {th }}$ century did not argue for complete standardisation and prefabrication, largely due to their desire for flexibility - 'It is the nature of the part to provide standardisation and uniformity. It is the nature of the whole to provide unique, specific combinations, that is, variation.' The ideal is one of optimisation rather than maximisation. Furthermore, the Japanese, often cited as the leaders in the use of S\&P, particularly in the residential sector, actually standardise and pre-assembly subunits which, when installed on site, make up rooms of differing sizes. The final building is designed such that it is hard to see that it has been pre-assembled, or that it is made up of standardised units (Bottom et al 1994 and Gibb 1999).

\subsubsection{Standardisation means standard (and therefore boring) buildings}

This was one of the most talked about topics in the CIRIA research, with vehement support both for and against. Clearly there are historical examples of building systems that have been shown (at least judged by the taste of many) to produce boring standard solutions. With aesthetic style being largely a matter of subjective opinion, many also write-off the work of the McDonald's team with their Drive-Thru restaurants. Such a dismissive approach however misses the main point of a single-minded client very sure of its business case, not being side-tracked into trying to obtain architectural awards. Actually as a design item, judged by the standards of any other industry sector, these modular buildings would score very highly.

Furthermore, when considered in a broader sense, standard components can be used to great effect to produce customised solutions. A classic historical example is the Charles Eames house that was constructed entirely from standard catalogue components (Table 1). Also the Georgian residential design system involved considerable standardisation yet has produced houses that many aspire to own and live in with the word 'boring' far from their minds.

The argument has already been made that whilst the parts may be standardised, the whole must provide variation - customised solutions from standardised components. This may also be why many suppliers actually play down the fact that their products are standard, believing that the customer wants to think that they are designed specifically for their particular project (but also perhaps because the supplier believes a premium price could be charged for special products). In some parallel research work (IMI 1999) in the cladding sector, Gibb has established that many so-called bespoke cladding systems (designed specifically for the project) are actually little more than adaptations from previous projects. A mechanical services supplier, working in the UK and several Scandinavian countries has contrasted two approaches to standardisation where in Scandinavia the approach is 'if you can't see it, standardise it' whereas in the UK it is often 'we must start from scratch for everything'. 
However, there is still a significant lobby, particularly amongst architects, that argues against standardisation in design. Fox and Cockerham (2000) describe four different types of design categories namely:
1. Bespoke
No standardisation except loose parts and materials
2. Hybrid
Standard sub-assemblies with bespoke interfaces
3. Custom
Standard components up to assembly level
4. Standard
Standard components with standard connections

They argue that few buildings fit into the standard or custom category and as such they claim that 'Egan's lean thinking recommendation is less applicable to architecture than an ability for agile thinking.'

It appears that the industry's dilemma over the worth, or otherwise, of standardisation is creating a smoke screen that makes accurate evaluation of success difficult to achieve. By concentrating on excellence in design, S\&P can produce exciting, innovative buildings that could not be seen as boring (e.g. Peabody Trust, Ladbrooke Grove, Hackney 1999).

\subsubsection{More or less? - The cost of pre-assembly}

'The use of elemental cost analyses, based on historical data, presents many problems when new designs and/or new production methods are introduced. In particular, it is insensitive to the complexity of construction method' (Groák 1992 p.103). This is particularly the case for S\&P where many of the benefits are realised elsewhere in the construction process (e.g. reduced site labour and associated costs). Taking an elemental view by considering the building element in isolation, it is not surprising that pre-assembled units may appear more expensive. For example, the overheads and set-up costs of the factory must be covered whereas for site works the equivalent costs are often 'lost' in the principal contractor's preliminaries.

Increased productivity in the factory should bring cost savings along with economies of scale. However, Groák found that 'the realities of manufacturing production for established systems, were that the manufacturer had to wait on orders via the general contractors. Supposed economies of scale were rarely realised, although better prices through bulk buying were achieved' (Groák 1992 p.135). Furthermore, in line with a free market economy, this paper argues that many manufacturers and suppliers seek the maximum price that the market will sustain. Therefore the tender prices quoted may not reflect the actual costs and therefore hinder sensible comparison with conventional construction.

\section{Realities of standardisation and pre-assembly}

\subsection{The benefits and implications of optimised standardisation and pre- assembly}

The CIRIA project found that the greatest benefit was gained when S\&P were used together and this section describes the benefits and implications of implementation. The CIRIA research included a number of contemporary case studies. The research team was keen to demonstrate real applications 'warts and all' rather than just present the theoretical benefits. The case studies are described along with the key lessons in Table 
2. It was found however, that in practice, the benefits claimed were rarely specifically measured but were based on client or project perception. The subject of developing an effective measurement method is being addressed in further work by CIRIA (CIRIA 2000).

Standardisation of processes and procedures enabled project teams to streamline the overall construction process, which was claimed to reduce wasted effort and project team resource. This potential existed even on individual projects, but clearly could be even greater for larger clients with repeat orders. Contemporary business systems, information technology and management techniques enabled standardised processes to be more sophisticated than had previously been the case thus addressing historical concern about inappropriate, bureaucratic procedural standardisation. Projects claimed that standard procedures increased confidence in project outcomes as stakeholders became more familiar with these processes (e.g. BAA's Genesis project - see Table 2).

Standardisation of products and components offered benefits from continual improvement as found in other industry sectors but often not realised with the one-off, unique project approach in construction. Interviewees considered that safety and productivity performance should improve as off-site and on-site personnel become more familiar with the materials and components. The fact that they are tried and tested was believed to control risk and increase reliability, both during the construction process and throughout the life of the building or facility - the building should perform reliably, be more easily maintained and require fewer spare parts. However, as explained previously, it was thought that benefits from repetition and mass production may not be realised and even if they were, they may not be passed on to the client.

It was found that, because pre-assembly brought the construction site into the factory where the environment was more controllable, safety, productivity and quality could all be improved. There should also be less waste and less impact on the environment. However, once again, there were few examples of metrics to enable effective measurement. Furthermore, these benefits will only be realised if the traditional sitebased practices and culture are not merely transferred to the factory but rather completely changed to reflect the manufacturing culture. The CIRIA work found that, by manufacturing and pre-assembling units before they would be needed on site, confidence that the project outcomes would be achieved was increased. This was particularly the case in terms of predictable price, cost and programme.

Even though pre-assembly changed the site processes and could actually increase the hazards in some cases (for example increased craneage), the installation processes, by their very nature, had to be thoroughly planned. It was claimed that this reduced the need for on-site problem solving and enabled site activities to be managed more effectively (e.g. Chek Lap Kok Airport - Table 2). Furthermore, pre-assembly made some projects viable when they could not have been built had they relied solely on site work (e.g. RAF Mount Pleasant, $2^{\text {nd }}$ Severn Crossing - Table 2). 


\begin{tabular}{|c|c|c|}
\hline \begin{tabular}{l|l} 
Project \\
\end{tabular} & Main $S \& P$ application & Key lessons \\
\hline $\begin{array}{l}\text { RAF Mount } \\
\text { Pleasant, } \\
\text { Falkland } \\
\text { Islands } \\
1985\end{array}$ & $\begin{array}{l}\text { Flat pack and volumetric units for } \\
\text { residential and welfare facilities - } \\
\text { shipped from UK }\end{array}$ & $\begin{array}{l}\text { Pre-assembly was the only viable option } \\
\text { Significantly reduced site labour force } \\
\text { Efficient use of shipping capacity } \\
\text { Early weatherproofing of units essential } \\
\text { On-site finishing was time consuming }\end{array}$ \\
\hline $\begin{array}{l}\text { Kansai } \\
\text { Airport, } \\
\text { Japan } \\
1993\end{array}$ & $\begin{array}{l}\text { Structural steel wings - shipped } \\
\text { from UK in containers } \\
\text { Pre-assembled on-site before } \\
\text { installation }\end{array}$ & $\begin{array}{l}\text { Project not possible without pre-assembly } \\
\text { Extensive use of IT benefited project } \\
\text { Concentration on manufacturing accuracy essential } \\
\text { 'Bespoke' details but still treated as a manufacturing } \\
\text { process }\end{array}$ \\
\hline $\begin{array}{l}\text { Vintners } \\
\text { Place, } \\
\text { London } \\
1993\end{array}$ & $\begin{array}{l}\text { High-quality volumetric office } \\
\text { washrooms for a speculative } \\
\text { commercial building }\end{array}$ & $\begin{array}{l}\text { Pre-assembly has benefits even with little } \\
\text { standardisation } \\
\text { Pre-assembly suits projects with a tight construction } \\
\text { programme, restricted site space, high quality finishes } \\
\text { and complex construction interfaces } \\
\text { Early involvement of manufacturers is essential }\end{array}$ \\
\hline $\begin{array}{l}\text { Second } \\
\text { Severn } \\
\text { Crossing, } \\
\text { UK } \\
1996\end{array}$ & $\begin{array}{l}\text { Precast concrete bridge piers and } \\
\text { deck sections } \\
\text { Steel/concrete composite deck } \\
\text { units }\end{array}$ & $\begin{array}{l}\text { Pre-assembly minimised on-site work in the river } \\
\text { Time is needed to plan for standardisation } \\
\text { Existing costing systems favour minimal material } \\
\text { solutions ignoring benefits of standardisation } \\
\text { Detailed, thorough planning is essential }\end{array}$ \\
\hline $\begin{array}{l}\text { Bathroom } \\
\text { units, } \\
\text { Denmark } \\
1998\end{array}$ & $\begin{array}{l}\text { Volumetric precast concrete bath } \\
\text { and shower room units used for } \\
\text { residential and institutional } \\
\text { buildings throughout Europe }\end{array}$ & $\begin{array}{l}\text { Application is accepted as the norm in many countries } \\
\text { Basic system has been developed over many years } \\
\text { Details change for each project but system is standard } \\
\text { Productivity, quality and health better in factory }\end{array}$ \\
\hline $\begin{array}{l}\text { Genesis } \\
\text { project, } \\
\text { Heathrow } \\
1998\end{array}$ & $\begin{array}{l}\text { Multi-storey car park } \\
\text { Part of a framework agreement } \\
\text { Extensive use of standard systems } \\
\text { Pre-assembly maximised } \\
\text { Benefits measured }\end{array}$ & $\begin{array}{l}\text { Simple buildings can use } 100 \% \text { S\&P } \\
\text { Repeat-order clients can obtain additional benefits } \\
\text { Measurement of S\&P is difficult, but beneficial } \\
\text { The variable cost is in connections and site work } \\
\text { 3D computer modelling aids S\&P application }\end{array}$ \\
\hline \begin{tabular}{l|} 
Chek Lap \\
Kok Airport \\
Hong Kong \\
1998
\end{tabular} & $\begin{array}{l}1998 \text { - } 129(36 \times 33 \mathrm{~m}) \text { structural } \\
\text { steel roof units for airport terminal } \\
\text { building, shipped from UK then } \\
\text { pre-assembled on-site }\end{array}$ & $\begin{array}{l}\text { On-site pre-assembly suitable for 'large' sites } \\
\text { Optimal balance between remote pre-assembly and } \\
\text { transport costs } \\
\text { Health \& safety risks reduced by less work at height } \\
\text { Handling logistics limit extent of pre-assembly }\end{array}$ \\
\hline $\begin{array}{l}\text { Modular } \\
\text { office } \\
\text { buildings, } \\
\text { UK } \\
\text { Circa } 2000\end{array}$ & $\begin{array}{l}\text { Whole buildings factory-assembled } \\
\text { One brick-clad on site, the other } \\
\text { left as factory-finished }\end{array}$ & $\begin{array}{l}\text { Standard modular buildings benefit 'one-off' clients } \\
\text { Cost and programme were predictable and less than } \\
\text { conventional }(<10 \text { weeks from contract to completion) } \\
\text { Variations are possible but limited and have cost and } \\
\text { programme implications }\end{array}$ \\
\hline $\begin{array}{l}\text { Modular } \\
\text { buildings, } \\
\text { UK } \\
\text { Circa } 2000\end{array}$ & $\begin{array}{l}\text { Circa } 2000 \text { - McDonald's Drive- } \\
\text { Thru, schools and hotel } \\
\text { applications of modular buildings }\end{array}$ & $\begin{array}{l}\text { On-site time significantly reduced ( } 26 \text { wks to }<2 \text { wks) } \\
\text { Standardised units enable rapid design/construction of } \\
\text { on-site elements (drainage, foundations etc.) } \\
\text { Pre-delivery test \& inspection is advised } \\
\text { Factory allows better productivity \& quality } \\
\text { Variety through different unit configuration and finishes }\end{array}$ \\
\hline
\end{tabular}

Table 2 - Contemporary case studies from CIRIA S\&P research 
In summary, the main potential benefits of S\&P were found to be increased predictability and efficiency. S\&P used together were seen to facilitate better management, but also to require better management. Understanding and commitment to S\&P by all parties was considered vital. Design decisions generally had to be made earlier than for conventional construction and critical information had to be established at the earliest possible stage. In an effort to address historical criticisms of S\&P, project teams worked hard to ensure that S\&P increased design choice, facilitated controlled innovation and ensured work of quality, aesthetic appeal and distinction. Managers had to be trained to control a manufacturing process that was considerably different to the on-site, often ad-hoc management of conventional construction.

\section{$4 \quad$ Closing thoughts}

This paper has suggested has defined standardisation and pre-assembly (S\&P) and has presented a historical and contemporary review of S\&P applications. The paper has claimed that success or failure of standardisation and pre-assembly will depend on the pragmatic response of industry to an urgent need - and industry's ability to predict what the developing needs will be. The CIRIA work found that clients' perception of the prevailing design culture has led to their demand for customised solutions and they will accept that these can be achieved using standardised products and processes combined with pre-assembly. It seems that very few clients actually strive for S\&P in itself. Instead, most desire to be seen to innovate, to have efficient, cost effective projects whilst caring for the environment and catering for the life cycle of their projects. Where S\&P can demonstrate that they will achieve these goals then they will be used. Lessons can be learned from the manufacturing sector, but houses are not cars and close comparisons should be treated with caution. By concentrating on excellence in design, evidence suggests that S\&P can produce exciting, innovative buildings that would not be seen as boring and would be cost effective, providing value for money throughout the project life-cycle. However, it was recognised that often in the past the end result has fallen short of this ideal.

The CIRIA work found that S\&P, if optimised and managed effectively, can help to overcome some of the costly unpredictabilities and resulting inefficiencies of the construction industry. It can increase confidence that value for money and a satisfactory performance to programme can be achieved, risk controlled and reliability increased. In addition, safety, health, productivity and quality performance should all increase. However, these benefits are not automatically achievable. They require understanding and commitment of the whole project team and early agreement of critical information. Furthermore, project management must respond to the different culture produced by replacing conventional construction activities with a manufacturing process. Failure to address these issues effectively may even result in increased time and cost and desired project outcomes not being achieved.

Steven Groák has played an important role in developing a realistic attitude to S\&P. The fact that he is not able to continue his work will be to the detriment of those in the industry who refuse to accept trite homilies but rather strive for real understanding of complex processes. 


\section{Acknowledgements}

The CIRIA research team:

Loughborough University

Ove Arup

Laing Technology Group

Consultants:

University of Sussex

Davis Langdon Consultancy
Alistair Gibb \& Richard Neale

Steve Groák

Gordon Sparksman

David Gann

Jim Meikle

\section{References}

Bottom, D, Gann, D., Groak, S. \& Meikle, J. (1994) Innovation in Japanese prefabricated house-building industries, Construction Industry Research and Information Association, London, 65pp.

BSRIA, (1999) Prefabrication and pre-assembly - applying the techniques to building engineering services, Compiled by Wilson, D.G.; Smith, D.H. \& Deal, J. The Building Services Research and Information Association, Bracknell, ACT 1/99, ISBN 0860225054

CIRIA (1997) Snapshot - Standardisation and Pre-assembly, Compiled by Gibb, A.G.F.; Groák, S. \& Sparksman, W.G., Construction Industry Research and Information Association, London, pp. 1-8.

CIRIA (2000) Standardisation, Pre-assembly and Modularisation - A Client's Guide, Construction Industry Research \& Information Association, London, Project Ref: RP579.

CIRIA (1999) Adding value to construction projects through standardisation and preassembly, Compiled by Gibb, A.G.F.; Groák, S.; Neale, R.H. \& Sparksman, W.G., Construction Industry Research and Information Association, London, Report R176.

Egan, Sir J. (1998) Rethinking construction: the report of the construction task force, July 1998, DETR, London, ISBN 1851120947.

Fox, S. \& Cockerham, G. (2000) Matching design and production, The Architects' Journal, E Map publications, 9 March, pp. 50-51.

Gann, D.M. (1996) Construction as a manufacturing process? - Similarities and differences between industrialised housing and car production in Japan, Construction Management and Economics, Vol 14, pp. 437-450.

Gibb, A.G.F. (1999) Off-site fabrication - Prefabrication, pre-assembly and modularisation, Whittles Publishing, Caithness, ISBN $187032577 \mathrm{X}$.

Gray, C. (1998) Construction as a manufacturing process, in Sarja A. (ed) (1998) Open and industrialised building, E \& FN Spon / Routledge, London, ISBN 0419 238409.

Groák, S. (1992) The idea of building, E \& FN Spon / Routledge, London, ISBN 0 419178309.

Herbert, G (1959) The synthetic vision of Walter Gropius, Witwatersrand University Press, South Africa, $48 \mathrm{pp}$.

Herbert, G (1984) The dream of the factory-made house: Walter Gropius and Konrad Wachsmann, MIT Press, Cambridge, Mass, ISBN 0262081407 
IMI (1999) Standardisation of Window \& Cladding Interfaces, research project funded by DETR/EPSRC under the Link Meeting Clients Needs through Standardisation programme.

Latham, M. (1994) Constructing the Team, Joint review of procurement and contractual arrangements in the UK construction industry, HMSO, London, ISBN 0 $11752994 \mathrm{X}$.

Russell, B (1981) Building systems, industrialisation and architecture, Wiley, New York, ISBN 0471279528.

Sarja, A. (ed) (1998) Open and industrialised building, E \& FN Spon / Routledge, London, ISBN 0419238409

White, R. (1965) Prefabrication: A history of its development in Great Britain, National Building Studies Special Report 36, HMSO, London. 